SISTEMA
ELETRONIICO
DE REVISTAS
SER I UfPR

\title{
Disaster risk management as a process to forge climate- resilient pathways: lessons learned from Cabo Verde
}

\section{Gerenciamento de riscos de desastres como um processo para criar caminhos resilientes ao clima: lições aprendidas de Cabo Verde}

\author{
Carlos Germano FERREIRA COSTA ${ }^{1 *}$ \\ ${ }^{1}$ Technical Consultant, Ministry of Science, Technology, Innovations, and Communications (MCTIC-Clima), Federal Government of Brazil, \\ Brasília -D.F., Brazil. \\ ${ }^{*}$ E-mail of contact: ccostapmp@gmail.com
}

Article received on June 9, 2019, final version accepted on March 19, 2020, published on June, 16, 2020.

ABSTRACT: Recurrently drought, high food prices, conflict, and market distortions are some of the mutually reinforcing factors of vulnerability and instability affecting the building of sustainable development pathways in the world. In this regard, the linkages between Climate Change, Risk Reduction, and Sustainable Development are cross-cutting and complex. Through a situational analysis, the paper seeks a correlation between the observed impacts of climate change and disaster events on the development levels of a Sahelian Archipelagic Country - Cabo Verde - in recent decades (1970 to present). It seeks to demonstrate policymakers and civil society the crucial role of combined Disaster Risk Management (DRM) methodologies, National risk profile analysis, and Human Development Index (HDI) methodology and development policies as mutually supportive tools to build resilience. In its core components, the study seeks the understanding of emerging causes of risks by addressing resource gaps in the development of Caboverdian context-based DRR solutions and approaches to increase capacity to build Climate-Resilient Pathways in similar circumstances.

Keywords: Mainstreaming Adaptation and Disaster Reduction into Development Program Methodology (MADRiD); Index for Risk Management Methodology (INFORM); situational analysis; transition studies; Disaster Risk Reduction (DRR); the Sahel.

RESUMO: $\quad$ Secas recorrentes, altas nos preços dos alimentos, conflitos e distorções de mercado são alguns dos fatores de vulnerabilidade e instabilidade que se reforçam mutuamente, afetando a construção de caminhos de desenvolvimento sustentável no mundo. Nesse sentido, os vínculos entre mudanças climáticas, redução de risco, e desenvolvimento sustentável são transversais e complexos. Através de uma análise situacional, este

Desenvolv. e Meio Ambiente usa uma Licença Creative Commons - Atribuição-NãoComercial-SemDerivações 4.0 Internacional 
artigo busca correlacionar os impactos observados das mudanças climáticas e eventos de desastres nos níveis de desenvolvimento de um país arquipelágico do Sahel — Cabo Verde — nas últimas décadas (1970 até o presente). $\mathrm{O}$ estudo busca demonstrar aos formuladores de políticas e à sociedade civil o papel crucial das metodologias combinadas de Gerenciamento de Riscos de Desastres (GRD), análise do perfil de risco, em nível nacional, o Índice de Desenvolvimento Humano (IDH) e políticas de desenvolvimento como ferramentas de apoio mútuo na construção de resiliência. Em seus componentes principais, o estudo busca entender as causas emergentes dos riscos, abordando as lacunas de recursos no desenvolvimento de soluções e abordagens de Redução de Risco de Desastres (RRD) baseadas no contexto Caboverdiano para aumentar a capacidade de alcançar caminhos resilientes ao clima em circunstâncias similares.

Palavras-chave: Metodologia de Integração de Adaptação e Redução de Desastres no Desenvolvimento (MADRiD); Índice de Metodologia de Gerenciamento de Riscos (INFORM); análise situacional; estudos de transição; Redução de Riscos de Desastres (DRR); Sahel.

\section{Introduction}

Climate change-related risk reduction calls for novel approaches to sustainable development that consider complex interactions between climate, political, social, and ecological systems as a process, not as an outcome (Manyena, 2006; UNDP, 2010; Denton et al., 2014) as new risks and correlations are emerging (UNDRR, 2019). These approaches should integrate current and evolving understandings of climate change consequences as well as conventional and alternative development pathways to meet the goals of sustainable development (Fleurbaey et al., 2014; IPCC, 2014a). These challenges require policymakers and civil society to review assumptions regarding the relationship between past, current, and future risks; at the same time, it is necessary to integrate Disaster Risk Reduction (DRR) and Climate Change Adaptation (CCA) into development policy and planning to allow improvement of decision-making processes at different scales over time. Such approach is unavoidable; as the decisions we make today are critical in ensuring a safe and sustainable world for everyone, both now, and in the future (Wilbanks \& Sathaye, 2007; Bizi- kova et al., 2010; Denton et al., 2014; IPCC, 2018). The era of hazard-by-hazard risk reduction might have come to an end (UNDRR, 2019); now present and future approaches to managing risk require a continuous learning from inaction and mistakes, ensuring that the emergence of improved processes of decision-making and a better understanding of the systemic and interconnected nature of risk drive the world towards a more sustainable context.

In this regard, droughts and extreme temperatures are among the most frequent climate-related disasters occurring across large portions of the globe, causing extreme and impressive consequences for the food security of rural households, having its impacts commonly poorly reported, especially from low and lower-middle-income countries (Rojas, 2018). Additionally, drought alone has affected more people in the world than any other natural hazard in the last 50 years, impacting large segments of the population and destroying the natural resource base, livestock and livelihoods, falling overwhelmingly on low and lower-middle-income countries (Jasen \& Barret, 2016; FAO, 2015; Kath et al., 2018). The impacts of drought are diverse and classified broadly as economic, environmental, and 
social (Wilhite, 2003). While the economic impacts of drought include increased commodity prices, demand for water, and credit, the social impacts include unplanned migration, poverty, reduced quality of life, and increased political conflicts (Zarafshani et al., 2016).

Even though the paper conceptualizes risks as a product of hazard, exposure, and vulnerability, multiple studies often do not incorporate both hazard and vulnerability factors when evaluating drought risk (Rajsekhar et al., 2015). As such, the primary objective of this study is to contextualize the crucial role of climate change-related risk reduction into development as a tool to induce Climate-Resilient Pathways in the Sahel, based on the risk profile and Human Development levels (Human Development Index -HDI) of a Sahelian Archipelagic Country -Cabo Verde. The paper assesses the observed impacts of historical hydrometeorological events and disasters during the beginning of the $21^{\text {st }}$ century and a compact characterization of natural hazard events in Cabo Verde from 1900 to 2018, against national and regional Human Development Index. It seeks to provide policymakers and civil society with an up-to-date outline about the usefulness of combined DRM methodologies to understand what kind of risk management is necessary and what kind of governance improvement can be achieved to fill DRR knowledge gaps based on the Caboverdian situational analysis by understanding the government's capabilities, capacities, and business environment. As the measurement of multidimensional vulnerability remains immature; systematic effort and sustained development of a more coherent, high-resolution understanding of vulnerability in society can enrich the operational and political dimensions of risk management (UNDRR, 2019).
The paper has a view of supplying learning lessons that could be translatable to other contexts. Due to the complex nature of the drought, the paper only investigated certain aspects in-depth, namely the governance process, including the role of some of the actors and institutional arrangements. At the same time, the paper expects to contribute to the DRM knowledge base by capturing issues that have emerged from national efforts making sure they inform the Sahel regional/international development context and risk reduction processes.

\section{Material and methods}

\subsection{Data and method}

This study presents analysis and discussion in the global, regional, and continental perspectives, targeting a Small Island Developing States (SIDS) in the Sahel, Cabo Verde. The paper aims to provide policymakers and civil society with an up-to-date outline about the usefulness of combined Disaster Risk Management (DRM) methodologies to understand what kind of risk management is necessary and what kind of governance improvement it needs, by discussing the observed impacts of climate change on development. Therefore, three sections structure the paper. Initially, it discusses and makes a correlation of national risk profile with human development levels based on the Human Development Index (HDI) inside the Sahel. Putting the political situation of Cabo Verde in context, the research adopted an approach to understanding the historical patterns of risks, vulnerability, and development. The paper assessed the observed impacts of the most current disaster event in the country —droughts 
- and informed about some recent developments in this context. The next sections briefly discuss the history of disaster events (1970 to present), with a focus on the 2017-18 drought events and its respective Government Drought Emergency Plan, with a final section discussing lessons learned and recommendations.

Cabo Verde is located in a region marked by high exposure to risks and vulnerability - the Sahel -besides, it is a SIDS. As a member of the Sahel, it presents peculiarities characterized by unequal rates of human development, recurrent drought, high food prices, market distortions, and rising regional inequalities. While, as a SIDS, it shares disproportionate challenges for sustainable development, and heightened vulnerabilities for natural and environmental disasters. Socioeconomic inequalities, fiscal constraints, health issues, and widespread poverty across islands increase the challenges that prove the importance of ensuring that growth is both sustainable and inclusive for everyone.

The paper supplied a brief description of the main drivers of development, economy, and governance of Cabo Verde, as people must be at the center of risk reduction management. By addressing government development interventions in agricultural and non-agricultural sectors, this approach sought to contextualize the crucial role of climate change-related risk reduction into development to ensure consistency of actions regarding the integration of risk information and development indicators. The paper focuses on Disaster Risk Management strategies, addressing the severity of the cumulative effects of historical and recent disaster events, especially droughts impacting agriculture and smallholder farmer's livelihoods. It discussed several national government interventions and re- source mobilization efforts to explain the national context - paying particular attention to the 20172018 drought events since agriculture and livestock compose the main sectors of economic activities for the people in rural areas in Cabo Verde. The paper supplied a historical characterization of impacts of the hydrometeorological disasters during the beginning of the $21^{\text {st }}$ century, and a compact characterization of natural hazard events in Cabo Verde from 1900 to 2018, as pieces of background information. Although the analysis of disaster impacts on the Caboverdian agricultural sectors is the main goal in this study, the analysis presents a brief description of non-agricultural sectors (tourism in particular), as this sector sustains much of the island's economy and government development efforts. Therefore, to properly contextualize Climate-Resilient Pathways towards more sustainable societies, a short section addressing non-agricultural information was included throughout the paper, according to government development interventions.

This is qualitative research. The paper utilizes secondary data and information from the EM-DAT database, the 2019 Index for Risk Management (INFORM), and relevant national environmental and risk reduction policy analysis from the Cabo Verde's government official documents - mainly related to the 2017-18 Government Drought Emergency Plan (EP). It also includes the analysis of more than 100 individual journals and search engines, donor reports, and international organization's reports (HDI, GFDRR, IPCC, OCHA, WHO, WMO, WORLD BANK, UN-OHRLLS, UNISDR, UNDRR, UNDP). This approach provided a costeffective way of gaining a broad understanding of current research questions and the multidimensional understanding of context, embracing different 
aspects of climate sustainability, risk reduction, and development in the country responding to the cascading and interlinked nature of risk and vulnerability.

Methodologically, the paper relies on the method of data and text analysis as an essential approach comparing data and information from various sources related to disaster management and emergency response. Moreover, the paper is fundamentally built around the integration of the Components 1 and 2 of the Mainstreaming Adaptation and Disaster Reduction into Development (MADRiD) program methodology, and data collection from a global, open-source risk assessment for humanitarian crises and disasters database - the 2019 Index for Risk Management (INFORM) (http://www. inform-index.org/). The primary responsibility of INFORM is to fill knowledge gaps regarding disaster events in Cabo Verde, being supported by data collected from the EM-DAT website (http://www. emdat.be/database) —average $21^{\text {st }}$ century - to contextualize country/regional/continental's risk profile, based on level estimates on disaster events (especially droughts), people killed and affected, as well as economic damage (based on available data).

The INFORM Index and the EM-DAT integrated a massive amount of information about risk and vulnerability. The analysis envisaged three dimensions of risk: (i) hazards and exposure, (ii) vulnerability; and, (iii) the coping capacity dimensions, allowing the graphic visualization of the country at the regional level, which contributed to a shared understanding of risk in its context. The research approach reflected the UNISDR's definition of risk and disasters to draw reliable information on the risk profile to support adequate decision-making analysis, as well as to justify and advocate for action for people affected by forgotten or unrecognized crises. The paper used a concept of risk that is equivalent to that of vulnerability. In this work, exposure and vulnerability - equivalent to sensitivity - and coping capacity - equivalent to adaptive capacity - have been adopted to support the correlation of concepts of risk, vulnerability, and exposure with human development levels. In this regard, to address vulnerability adequately, the paper provided a framework for identifying the social, economic, and environmental causes of a disaster based on recognized international methodologies. This combination of methodologies is innovative because it helps in the harmonization and linking of policy, planning, and programming frameworks for DRR and CCA within the broader context of poverty reduction and sustainable development agendas. At the same time, it is useful to bridge DRM knowledge gaps between historically incomplete disaster impact assessments and ill-informed policy formulation by re-directing policy attention to the underlying causes of vulnerability rather than to its results and negative impacts that follow triggering events such as drought (WDCC, 1998). Furthermore, the study paid considerable attention to the emergence of a general corporate social responsibility framework for all emergency operations in the country, according to the nature and urgency of the recent drought event, generating the potential of envisage the alignment of coherent natural and social systems in the design of policies and investments at all scales. 


\subsection{Context and study area}

Cabo Verde is a Small Island DevelopingState (SIDS) in the mid-Atlantic, being made up of ten islands and nine islets, found between latitudes $14^{\circ}$ $28^{\prime} \mathrm{N}$, and $17^{\circ} 12^{\prime} \mathrm{N}$, and longitudes $22^{\circ} 40^{\prime} \mathrm{W}$, and $25^{\circ} 22^{\prime} \mathrm{W}$. The country is $600 \mathrm{~km}$ far from the Senegal coast in West Africa, in the Sahel (GoCV, 2007). The country has an estimated population of 520,500 who live on nine of these islands. Arable land represents only $10 \%$ of its territory, and the country has limited mineral resources. As an archipelagic country of volcanic origin in the Sahel sub-region, it is characterized by a dry tropical climate with two distinct climatic seasons - a long dry season and a temporal and spatially concentrated rainy season. It presents an overly sensitive environmental system with a high degree of fragility and vulnerability in front of the occurrence of extreme natural phenomena, with a high likelihood of droughts between November and June (56\% of the precipitation between July and September) (McSweeney, 2010). Besides, the relatively high population density in some islands, inadequacy of infrastructure, and limited institutional capacity, as well as lack of natural resources, work in tandem to increase the impacts of recurrent drought and disaster events in large portions of the territory (GoCV, 2007; GoCV, 2013).

The country faces a wide range of natural disasters, market, fiscal, and socioeconomic asymmetries, exposing its economy and population to highly probable global changes, which threaten the country's long-term economic growth and resilient development. In recent years Cabo Verde has suffered from: (i) extreme rainfall events that have led to several floods across the country including those in
São Nicolau (2009), Boavista (2012), São Miguel (2013, with damages estimated at US\$ 2.6 million), and Santo Antão (2016, with damages estimated at US\$ 7 million) (GoCV, 2016); (ii) a volcanic eruption in 2014-15, in the island of "Fogo", which displaced all 994 people living in the caldera, and resulted in damages and losses estimated at US\$ 28 million; (iii) hurricane Fred in 2015, which caused damages estimated at US\$2.5 million; and finally, (iv) an intense drought event occurred in 2017-18 that might have affected up to 70,000 people (13 percent of the population), according to Government's estimates (GFDRR, 2017; WB, 2018b).

\section{Results and discussion}

Since the 1970s, Cabo Verde has reported several episodes of drought. The registers indicate that the main events occurred between 1968 and 1973, another in 1977 (DW, 2018), followed by extreme events between 1981 and 1983, when the precipitation levels recorded were 50 to $70 \%$ lower than the median precipitation of the previous period (1941-90). According to the EM-DAT Cabo Verde, droughts stood for the most common type of event, affecting the archipelago between 1900 and 2018 (Table 1).

The Intergovernmental Panel on Climate Change (IPCC) 2018 Special Report on Global Warming of $1.5^{\circ} \mathrm{C}$ brings a new sense of urgency for risk reduction efforts. Climate change is a significant driver of disaster losses and failed development. It amplifies risk (UNDRR, 2019). Climate change is expected to affect Cabo Verde in several ways: (i) through a projected sea-level rise of $0.26 \mathrm{~m}$ to $0.98 \mathrm{~m}$ for $2081-2100$; by (ii) modifying rainfall patterns; and, (iii) storm intensity, which is positively correlated with sea surface 
temperatures, which is expected to increase by 0.7 to $2.5^{\circ} \mathrm{C}$ by the $2060 \mathrm{~s}$, and by 1.2 to $3.7^{\circ} \mathrm{C}$ by the $2090 \mathrm{~s}$ (McSweeney, 2010; IPCC, 2013).

Human-generated greenhouse gases and atmospheric particles were affecting global drought risk as far back as the early $20^{\text {th }}$ century, connecting humangenerated emissions and drought at near-global scales (Marvel et al., 2019), reducing agricultural productivity, and generating food crises over the $20^{\text {th }}$ century and at the beginning of the $21^{\text {st }}$ century. In the specific case of Cabo Verde. It might have acted synergically to an acceleration of rural exodus and migration (both among islands and internationally). Despite the commotion food crisis in the Sahel often causes in the Western world. Often, Caboverdian food national crisis usually goes unnoticed due to several factors related to limited appeal and influence in regional and international terms. Also, due to the high frequency of drought events and the erratic nature of disaster management in the country, local society has generally moved from one disaster to another with little, if any, reduction in risk, indicating that reactive crisis management usually defines the management pattern of droughts historically (Karami, 2009). On this subject, disaster and recurrent drought events have multiple impacts on socio-economic sectors and development. These impacts are expected to increase in the coming years due to the non-stationary nature of climate variability and change (Dabanli, 2018).

In this context, drought risk can be understood as a common effect of drought hazard (likelihood) and drought consequence (vulnerability). Often, droughts have their frequency, duration, and severity determining drought hazard as drought impacts on different levels, ecosystems, society, and the economy according to their correlation on the vulnerability of the affected system (GWP CEE, 2014). In this respect, the paper admits that drought vulnerability and risk assessments are essential parts of a better understanding of the drought phenomenon. The paper adopts a linkage of vulnerability and risk based on hydro-meteorological and actual socio-economic data for Cabo

TABLE 1 - Natural hazard events in Cabo Verde (1900-2018).

\begin{tabular}{|c|c|c|c|c|c|}
\hline Disaster type & Disaster subtype & Events count & Total deaths & Total affected & $\begin{array}{c}\text { Total damage } \\
\text { ('000 US\$) }\end{array}$ \\
\hline Drought & Drought & 10 & 85000 & 40000 & - \\
\hline Storm & Tropical cyclone & 3 & 41 & 7722 & 4100 \\
\hline Insect infestation & Locust & 2 & 0 & - & - \\
\hline Epidemic & Viral disease & 1 & 6 & 20147 & - \\
\hline Volcanic activity & Ashfall & 1 & 0 & 6306 & - \\
\hline Volcanic activity & Lava flow & 1 & 0 & 2500 & - \\
\hline
\end{tabular}

SOURCE: Adapted from EM-DAT (2018): the emergency events database -Universite Catholique de Louvain (UCL) -CRED (2018), D. Guha-Sapir -www.emdat.be, Brussels, Belgium. Created on February 13, 2019. 
Verde, due to the lack of proper integrated drought risk assessments in specific contexts, which has led to poor understanding of drought phenomenon at the local level in the country. Besides, many studies have emphasized that the assessment of drought risks, combining socioeconomic data, hazard prioritization and vulnerability of a region is a suitable way to provide new knowledge and better understanding of droughts events (Shahid \& Behrawan, 2008; Verdon-Kidd \& Kiem, 2010; Lin et al., 2011; Rajsekhar et al., 2015; Jia \& Wang, 2016; Pei et al., 2016).

\subsection{Cross-cutting and complex linkages between climate change, risk reduction, and sustainable development}

\subsubsection{Risk profile and Human Development Index (HDI)}

In a counterbalanced relationship between the risk of what (natural and human-induced hazard), and the risk to what (population), the conceptualization of the information presented in the analysis of the INFORM (2019) showed remarkably exciting findings, defining the hazard \& exposure dimensions. At the country level, the index indicated an incredibly minimal risk of human-induced hazards, such as conflicts, which is marginal, only 0.1 . However, as expected, the physical dimensions of exposure associated with natural hazards are considerable (1.9), while risks of hazards and exposure to droughts as exceptionally high (6.6 out of 10). In this regard, the vulnerability dimension - contextualized around economic, political and social characteristics that related to the levels of Human Development - , provided the understanding that, at least, a medium predisposition of exposed populations to be affected or to be susceptible to the damaging effects of drought is commonly expected. However, the data also referred to the low ability of the country to cope with disasters in terms of formal and organized activities as well as lack of effort of the country's government to manage Disaster Risk Reduction (DRR) sectoral approaches, and at the same time, invest in sustainable infrastructure successfully. A higher frequency of droughts and storms, along with a lower rank on its vulnerability score, as well as highly unequal land ownership and low land assets among the poor, composes many of the exposures to vulnerability and risks that remain misperceived in Cabo Verde (WB, 2018c). In this regard, Figure 1 helps to visualize the Cabo Verde risk profile and trends for selected hazard and exposure, vulnerability, and coping capacity indicators.

In 2018, examined droughts, extreme temperatures, floods, and storms accounted for most of 58 million people affected by natural hazards globally, according to an analysis of 231 extreme events (EM-DAT, 2018). In total, 9.3 million people were affected by this type of disaster, especially in Kenya (3 million), Afghanistan (2.2 million), and Central America (2.5 million), including migration hotspots Guatemala, Honduras, El Salvador, and Nicaragua. Europe suffered persistent heatwaves and drought exposure that affected the population and health systems, with overall limited impacts, due to higher levels of Human Development, according to the Centre for Research on the Epidemiology of Disasters (CRED, 2018) in its EM-DAT (Emergency Events Database) (CRED, 2018). The impacts of extreme weather events in 2018 continued the total disaster-related economic losses and fatalities trends between the end of the $20^{\text {th }}$ century and the beginning of the $21^{\text {st }}$ century trend (Table 2). 


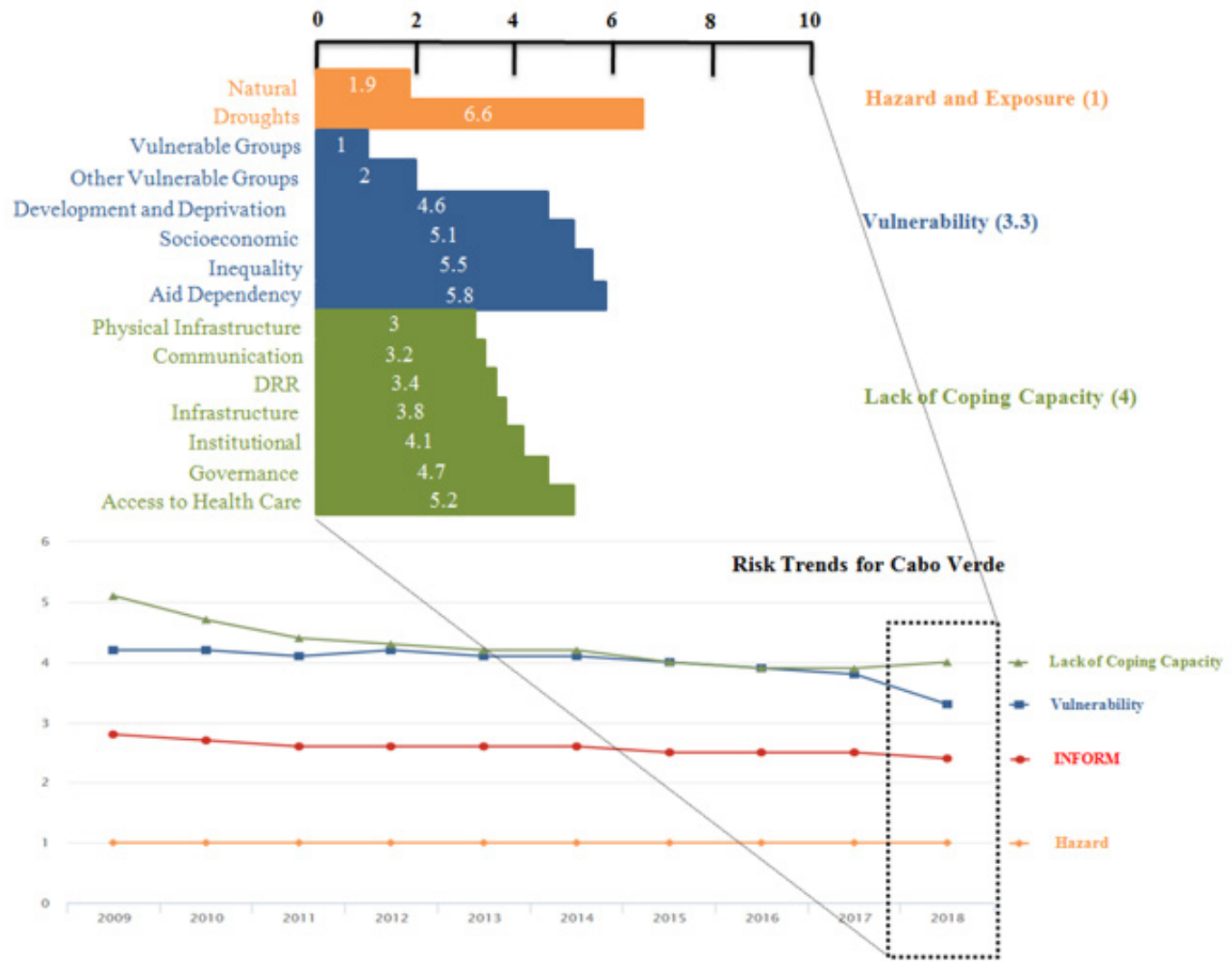

FIGURE 1 - Cabo Verde risk profile (2018), and 2009-2018 trends for selected hazard and exposure, vulnerability, and coping capacity indicators. SOURCE: Adapted from INFORM (2019).

TABLE 2 - Total number of people affected by hydrometeorological disasters (average 21st century and 2018).

\begin{tabular}{lcc}
\hline \multicolumn{1}{c}{ Event } & Average (2000-2017) & $\mathbf{2 0 1 8}$ \\
\hline Drought & $58,734,128$ & $\mathbf{9 , 3 6 8 , 3 4 5}$ \\
Extreme Temperature & $6,368,470$ & 396,798 \\
Flood & $86,696,923$ & $35,385,178$ \\
Storm & $34,083,106$ & $12,884,845$ \\
\hline Total & $185,822,627$ & $58,035,166$ \\
\hline
\end{tabular}

SOURCE: Adapted from EM-DAT (2018): the emergency events database -Universite Catholique de Louvain (UCL) -CRED (2018), D. Guha-Sapir -www.emdat.be, Brussels, Belgium, 2018. 
While the majority of fatalities, in this period, were due to geophysical events - mostly earthquakes and tsunamis - , floods, storms, droughts, heatwaves, and other extreme weather events disasters caused $91 \%$ of all occurrences, leading to the global loss of 29,921 lives between 2000-17, and an additional 4,988 deaths in 2018 (Table 3).

In this regard, the Sahel usually sufferslong-term effects on the reduction of food access and availability because of the disruption of agricultural livelihoods and food production due to droughts and conflicts (Caniato et al., 2017; Chatzopolous et al., 2019; UNISDR, 2019). In this context, there is a need to understand emerging risks, as the lack of accurate information on the real effects of disaster events in the social tissue and national economies characterize decision-making processes regionally. Additionally, these countries face increasing challenges related to rapid and unplanned urbanization (GoCV, 2017b). Moreover, insufficient reporting from drought and extreme temperatures events hinder a better understanding of the real impacts of disasters at the country level, mostly due to methodological difficulties in registering deaths and the severe consequences caused by droughts and extreme temperatures, and the lack of involvement of the most vulnerable in local DRR strategies and planning (UNDRR, 2019).

\subsubsection{Cabo Verde in the sahelian context}

In this scenario, climate change is expected to increase the magnitude and frequency of hydro-meteorological hazards in the coming decades -including tropical storms, hurricane activity, and droughts - negatively affecting economic growth and human development (IPCC, 2013, 2014a, 2014b, 2018; ODI \& CDKN, 2014). Granted that, short-, medium- and long-term policies, programs, and practices require the integration of climate change adaptation and risk reduction into development to support the building of climate resilience, and safeguard socio-economic gains, and promoting social equality. On top of that, the geopolitical and climate dynamics that define Cabo Verde can hardly be grasped without reference to the broader Sahara region that contains it (Figure 2) (Lacoste, 2011; EU, 2012; ODI \& CDKN, 2014).

Table 3 - Death toll by hydrometeorological disasters (average $21^{\text {st }}$ century and 2018).

\begin{tabular}{lcc}
\hline \multicolumn{1}{c}{ Event } & Average (2000-2017) & $\mathbf{2 0 1 8}$ \\
\hline Drought & 1,361 & 0 \\
Extreme Temperature & 10,414 & 536 \\
Flood & 5,424 & 2,859 \\
Storm & 12,722 & 1,593 \\
\hline Total & 29,921 & 4,988 \\
\hline
\end{tabular}

SOURCE: Adapted from EM-DAT (2018): the emergency events database -Université Catholique de Louvain (UCL) -CRED (2018), D. Guha-Sapir -www.emdat.be, Brussels, Belgium, 2018. 


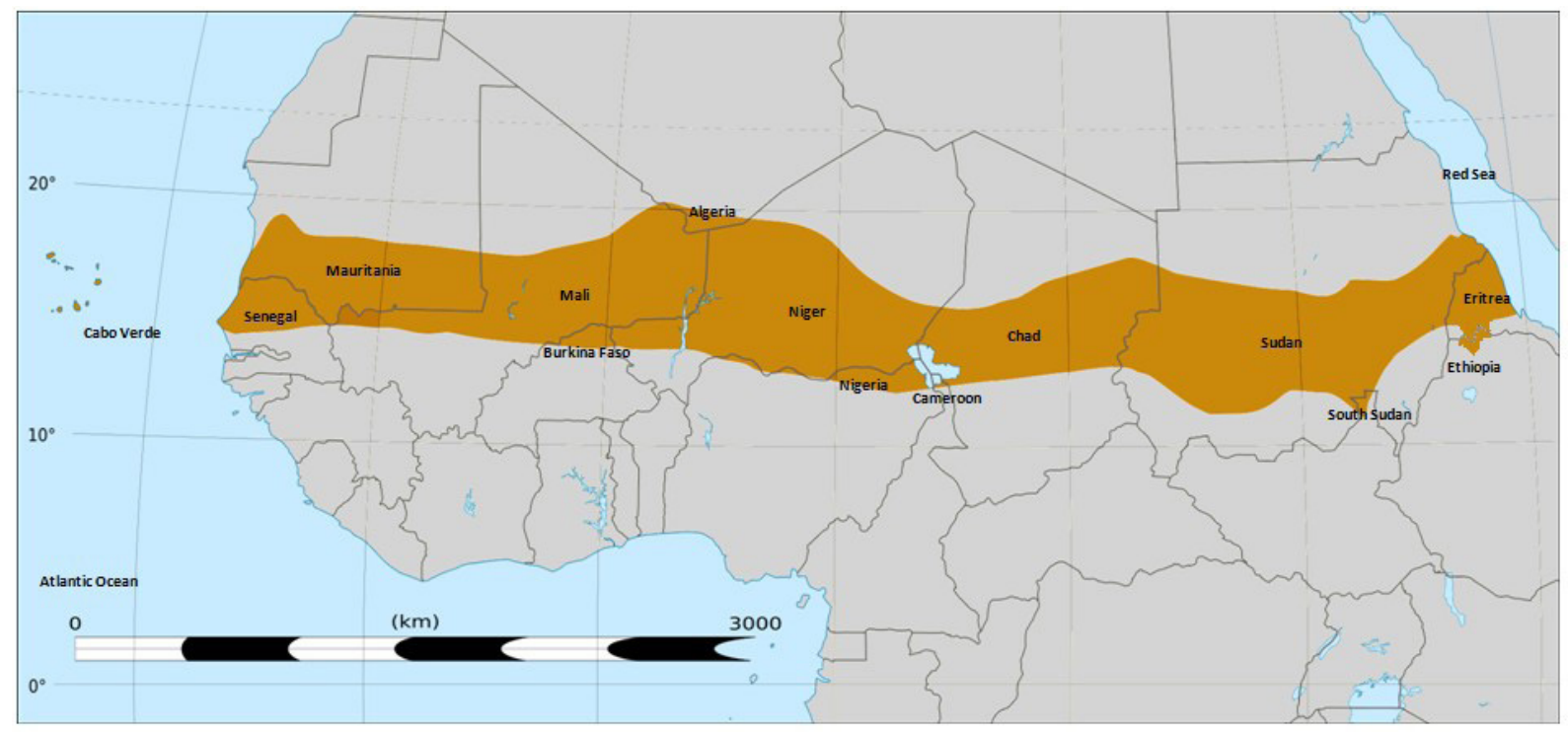

FIGURE 2 - Map of Sahel.

SOURCE: Adapted from blankmap-africa2.png (WC, 2018). Modifications made by Dr. Ferreira Costa. Sahelian African land is shown in orange on the lines of $200 \mathrm{~mm}$ (north), and $600 \mathrm{~mm}$ (south) mean 20th-century annual rainfall. It includes the islands of Cabo Verde, but not includes other areas in Africa with the same rainfall statistics.

On this matter, the location of Sahel corresponds to the geographic area occupying the southern belt of the Sahara Desert and Tuareg settlements (FES, 2011; STRATFOR, 2012). Even though the limits of Sahel are a subject of some dispute (EU, 2012), in this research, we adopt a broad definition. The paper refers to the Sahel as the space delimited by the Sahara in the north, the Atlantic Ocean in the west, the Red Sea Basin in the east and extreme north of Nigeria/Cameroon in the south, as the 'broader Sahara' geopolitical region within which that inserts the Sahel. In this regard, the Sahel region of West Africa is well known as a region of conflict, environmental degradation, food insecurity, water scarcity, drought, and desertification (Algamal, 2011; WB, 2011; EU, 2012; Couttenier \& Soubeyran, 2013;
CCAPS, 2014; Porkka et al., 2016; FAO et al., 2018). All recent decades commenced in the early 1970s, have witnessed reports on drought, which is seen by many authors to be both widespread and persistent, having a significant and long-lasting negative impact on human development (Agnew \& Chappel, 2000; Hall et al., 2014; Masih et al., 2014; Miyan, 2015). Besides, a combination of factors including violent extremism, abject poverty, demographic explosion, high food prices, low agricultural production, as well as the inability of affected households to recover from the incessant food and nutrition crisis, exacerbated the region's vulnerability posing immense challenges for 150 million people across the Sahel (WB, 2011; Porkka et al., 2016; OCHA, 2013; 2017; 2018). In this sense, conflict and drought remain at the pri- 
mary drivers working concurrently to historically leave more than 23 million people food insecure in West Africa (OCHA, 2017; 2018). Moreover, as for June-August 2018 -a period of intense droughts and widespread food crisis -, over 10.6 million people were considered in phase Crisis and above of projected food insecurity situation in the Sahel and West Africa (Cadre Harmonisé phase 3, 4, and 5; FAO, 2018). Regarding Cabo Verde, estimates showed about 68,810 people were facing distinct levels of food and nutrition deprivation in 2017, with a worst-case scenario of 139,000 people affected by the end of 2018, which accounts for $27,8 \%$ of the entire country's population (GoCV, 2017a).

Furthermore, the impacts of climate change are creating increasingly tricky conditions for traditional agriculture and animal husbandry developments in the broader Sahara region. It makes it essential to view the Sahel and Maghreb - which often face related challenges and constraints - as a whole (ODI $\&$ CDKN, 2014; GoN, 2018). Studies suggest that the degrees of suffering and vulnerability to risks can be commonly determined by insufficient levels of economic development, rather than simple exposure to natural hazards per se (CRED \& UNISDR, 2018). Agriculture, in this context, is the economic sector most affected by increasing variability of water resources globally - a dynamic situation that adds new layers of challenges as climate variability and conflict events increase. Agriculture might be remarkably vulnerable in socioeconomic terms due to the dependency of rural communities in developing countries. At the same time, it stands for a crucial element for sustainable development in the Sahel and Maghreb regions (FAO et al., 2017; 2018; WWAP \& UN-WATER, 2018; Thulstrup et al., 2018).
Regarding Human Development, many countries in the sub-region of Sahel - Niger (189 $)$ and South Sudan $\left(187^{\circ}\right)$ - are at the bottom of the UNDP Human Development Index (HDI, 2018), with low scores on health, education, and living standards. Cabo Verde is ranked at the $125^{\circ}$ position, in a medium level of Human Development. Notwithstanding, registers the second higher HDI in the subregion after Algeria - which is rated 85 - placed at the top spot in the Sahel cluster in this research (Figure 3) (HDI, 2018). All the same, the countries in the Sahel region have seen little progress in terms of social, economic, political, and human development. Substantially because corruption, inadequate environmental legal frameworks, poor governance, and low state capacity have been harming human development, severely limiting socioeconomic potentialities (EU, 2012).

Given empirical evidence, and due to specific contexts of vulnerability, many temporal, spatial, socio-economic, and biophysical factors interact differently according to the context having significant influences on the degree of vulnerability of the region (CSIRO, 2008). In this regard, the Intergovernmental Panel on Climate Change (IPCC, 2013; 2014a; 2014b; 2018) has provided an operational definition for vulnerability as a guide. It usually emphasizes strategies to reduce the impact of exposure and sensitivity, building adaptive capacity. Notwithstanding, measuring vulnerability remains complicated, given that vulnerability is not a directly observable phenomenon. Granted that, the present study endeavors to reflect a process-oriented view to vulnerability. The analysis of the INFORM (2019) showed a detailed picture of the risk profile of Cabo Verde and its comparable components across Sahelian countries (Figure 4). Besides, the INFORM (2019) described most of the countries in the Sahel region at increasing 
risk from humanitarian crises and disasters that could overwhelm national response capability. From the 12 countries in the world with the highest overall risk, six states are part of the Sahel Cluster (Chad, Ethiopia, Nigeria, Sudan, and South Sudan presenting Very High risk, and Mali at a High Risk), according to the INFORM Global Crisis Severity Index.

\subsubsection{The current disaster risk management and climate-resilient development strategies in the caboverdian context}

Despite the history of natural hazards in the country. Until recently, there was no clear mandate for Disaster Risk Management (DRM) in Cabo Verde. An almost complete absence of adequate Disaster Risk Reduction (DRR) financial instruments for disaster and emergency response represented a situation that started to change in 2017 (GoCV, 2017a) when the International Community started to invest massively in risk reduction in the country. Historical limited institutional capacity, as well as a strong focus on reactive response to disasters, exarcebated the underlying factors driving risk management at the national level - especially those related to climate change (WB, 2018a). Since then, the country has sought to strengthen its institutional and legal DRM/DRR and CCA frameworks to ensure risk-informed sectoral policy and infrastructure (ACP-EU, 2019), and territorial planning, as well as increasing the financial capacity to manage impacts associated with disaster and climate-related shocks.

Politics in Cabo Verde have been consensus-oriented since its independence from Portugal in

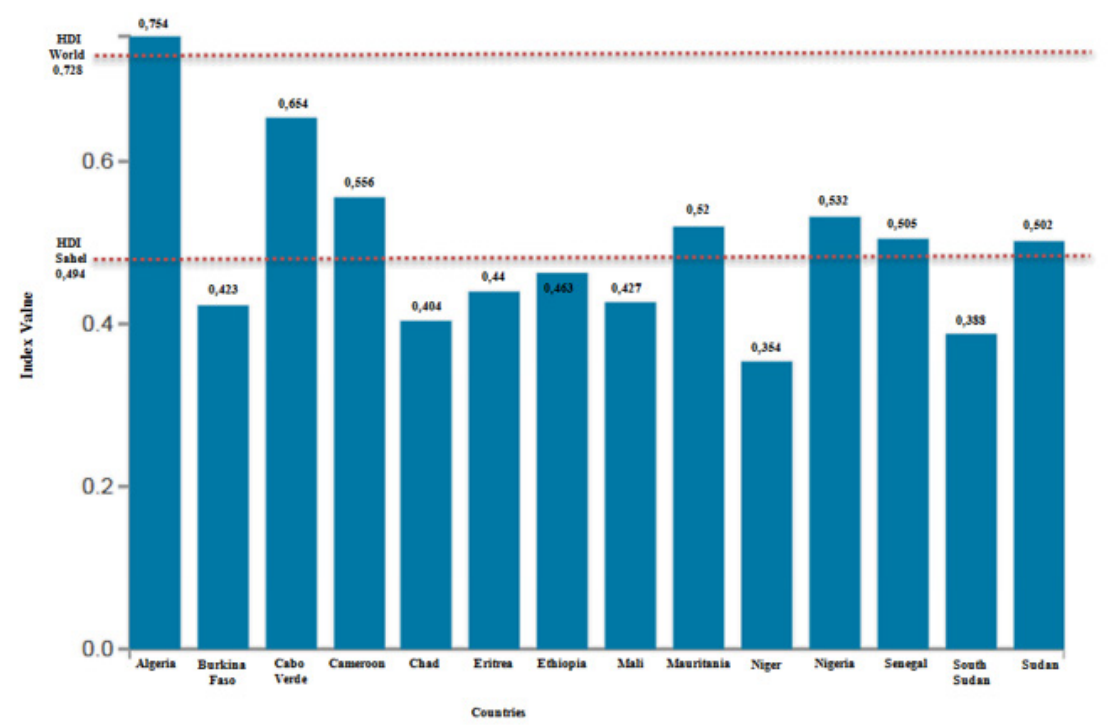

FIGURE 3 - Human development index for selected sahelian countries compared to the sahel cluster and the world 2018 index values (values of 2017).

SOURCE: Adapted from HDI, 2018; Human Development Index (HDI) values: (i) very high human development -0.894; (ii) high human development -0.757 ; (iii) medium human development -0.645 ; low human development -0.504 . 


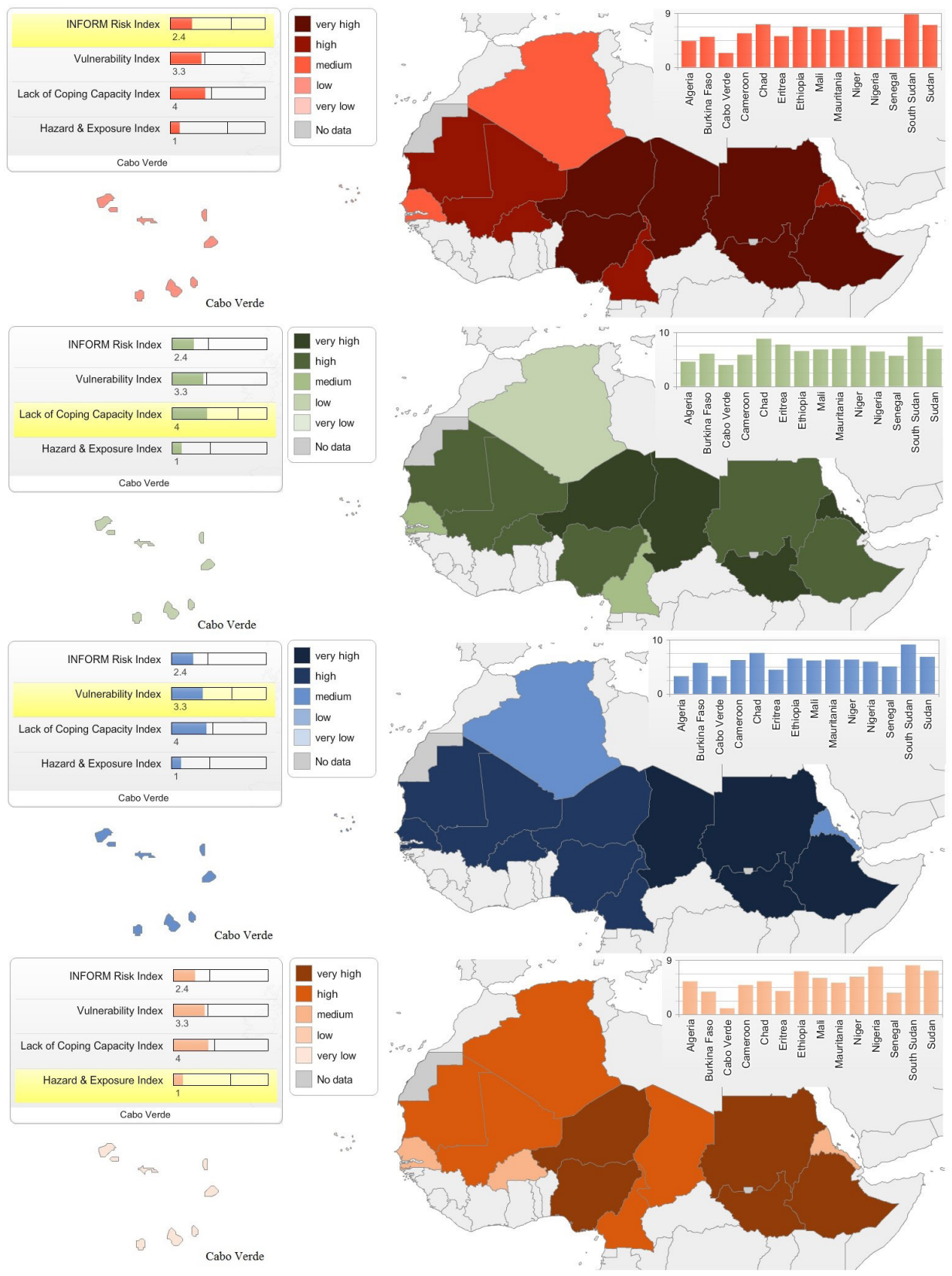

FIGURE 4 - 2018 Inform risk profile for the Sahel, Cabo Verde in evidence, informing hazard and exposure, vulnerability, and coping capacity. Cabo Verde indicators highlighted.

SOURCE: Adapted from INFORM (2019). 
1975. Besides, Cabo Verde has not experienced a single coup d'état since then. Parties in power alternate regularly through free and fair elections. In recent years, policy reforms included attention to increase long-term resilience and ability to recover from the adverse impacts of disasters including efforts to make the country more resilient to climate change following its Sustainable Development Strategic Plan 2017-2021, and adopting concepts of DRM and CCA integration in its National Disaster Risk Reduction Strategy.

Despite the challenges associated with being a SIDS economy, Cabo Verde witnessed spectacular social and economic progress between 1990 and 2008, driven mainly by the rapid development of all-inclusive tourist resorts (WB, 2019). Between 2001 and 2015, the country experienced an essential reduction in poverty rates, driven by the economic growth of the service sector - according to the national poverty line, the poverty headcount decreased from $57.9 \%$ to $35 \%$, and extreme poverty dropped from $30.2 \%$ to $10.6 \%$. Although poverty rates in urban areas were $27.7 \%$, and $48.3 \%$ in rural areas and income inequality remained high in 2015 (Gini of 47.2, in 2007) (WB, 2019). Currently, the Government of Cabo Verde (GoCV) enhanced a governance framework for the tourism sector to carry out the country's tourism diversification agenda. Aimed at better attract, facilitate, retain, and grow investment by diversifying tourism sector and increasing the inclusiveness of tourism-led growth by strengthening the competitiveness of local Micro, Small, and Medium Enterprises (MSMEs) to benefit from tourism growth (WB, 2016). Tourism remains the primary driver of Cabo Verde's economy, being grounded in sunny year-round weather, beautiful beaches, stable democracy, limited security risks, and proximity to Europe and Latin American countries (WB, 2019).

As a result, the country graduated recently from the Least Developed Country category (LDC) in 2007, due to broad government development interventions in non-agricultural sectors. Particularly on this matter, the graduation from the LDC category further raised a new set of challenges to finance sustainable development in the country. The graduation coincided with the global financial crisis (2008), driving Cabo Verde into the middle-income trap (UNDESA, 2015, 2018a, 2018b; OECD, 2019). From 2009 through 2015, economic growth decelerated significantly, a result of the protracted impact of the global financial crisis. Countercyclical fiscal measures did not restore growth and instead led to a sharp increase in the stock of debt (WB, 2019).

As poverty both in the country and in the Sahel subregion has usually been defined in absolute terms, and these countries have been marked by persistent inequality, as measured by relatively high food, water, and socioeconomic insecurity. The mismanagement of the transition, not targeting ample country priorities, being limited to specific sectors, certainly added further risks to development setbacks in the country (OECD, 2019).

Moreover, the Caboverdian characteristics of insularity and geographical disparity, as well as disperse small populations, amplifies national vulnerability. Even though Human Development in Cabo Verde has made great strides, rising regional inequalities and poverty across islands show the need for further actions, and the importance of ensuring that growth is both sustainable, inclusive, and risk-informed (UNDESA, 2018a). The country's small population is spread across nine islands that are scattered within a large water area, which 
constitutes a significant constraint to growth and integrated development. It limits economies of scale and creates significant connectivity issues, as well as challenges for service delivery, including energy, water, education, and health (WB, 2019).

In this regard, added economic and environmental vulnerabilities, beyond income per capita, intensify the challenges for a successful economic transition paying its share to keep Cabo Verde into the middle-income trap (OECD, 2019). Under this framework, Cabo Verde is still struggling to address some of the ills of underdevelopment - namely poverty, vulnerability, and inequality - a situation that highlights the importance of addressing structural economic and environmental constraints that limit both national and local development processes.

Nonetheless, in response to the severe 2017-18 drought event, there was the development of a range of innovative technical and institutional actions, some of which responded to the crisis and others that aimed at its causes and drivers. Despite the frequent occurrence of unmanaged drought events before 2017, it is possible that the current political and economic situation triggered a novel approach to responding to droughts. The government seemed especially concerned about the drought in 2017 and was able to intensify national coordination and articulation among many different actors when the country declared the need for international support towards the end of 2017. Moreover, as the drought progressed, various assessments were undertaken. Local governments were included in the decision-making processes, receiving support from the national government when declaring emergency appeals locally.

The severe drought and food crisis started in 2017, was referred to as the worst drought since
1977 (DW, 2018), and due to cumulative adverse outcomes of previous drought events, prompted the government to react and look for sustained solutions. According to the Government Drought Emergency Plan, some 17,203 rural households (62.3\% of them) were vulnerable to the situation of low agricultural production in the period 2017 2018, due to the ongoing drought crisis. The drought emergency-affected children, disabled people, and mono-parental families, led by women disproportionately, as the prevalence of undernourishment usually affected between $14 \%$ (2005) to $12,3 \%$ (2016) of the population (FAO \& ECA, 2018).

To highlight the importance of the situation, in 2014, the GoCV reported a severe drought event, followed by irregular and insufficient rainy season in the period 2015-2016 with cumulative impacts on recent drought events on agriculture, substantially affecting people's livelihoods since agriculture and livestock are the main sectors of economic activities for the people in rural areas. Agriculture employs $15 \%$ of the population and continues to be adversely affected by the impact of the year-long drought in 2017 (WB, 2019).

The decreasing income levels born further adverse consequences on such other aspects of the population's well-being as nutrition, health, and education. Notwithstanding, poor reporting from drought and extreme temperatures events continue to hinder a better understanding how these events damage the social tissue, affect smallholder production, drive uncertainties, and increase local and national exposure to climate-related risks ( $\mathrm{GoCV}$, 2007; GoCV, 2013; 2016; 2017b; EM-DAT, 2018).

Due to the severity of the 2017-18 drought event, an intervention strategy was developed (GoCV, 2017b). The proposed framework led to the 
creation of a permanent Technical Steering Team (ETP) — an Inter-Ministerial Task Force - responsible for the management and the implementation of the EP. The ETP counted with clear orientations about coordination and responsibilities to fill public governance gaps by exploring related society-stakeholders-government interactions for risk reduction, emergency response, and future climate resilience building. The government approach adopted a general corporate social responsibility framework for all emergency operations. It included the analysis of different institutional articulation and cooperation between involved actors, institutional cooperation with specialized development agencies, as well as the design of participatory approaches involving the beneficiaries, the central and local administration authorities, the private sector, and civil society organizations (GoCV, 2017b). In this sense, the usefulness of this approach in the long run, as well as its replicability to other contexts, is going to be subject to further analysis in additional research.

The intervention strategy also included the phasing out of actions according to their nature and urgency guided by the adoption of spatial strategies to conduct data and information collected in the field, assessment analysis, dissemination of information, and the implementation of awareness-raising campaigns through official communication channels. The approach tried to ensure consistency of actions and to reconfigure resource access, control, and crisis management (GoCV, 2017b). Although climate change responses can contribute significantly to climate-resilient development pathways, some of the critical elements of resilience lie in sustainable development implementation correlating benefits from individual indicator progress with the others (Denton et al., 2014). In this regard, the primary concern is responding to the negative impacts of climate change, taking both short- and long-term approaches to managing adaptation in the face of the changing climate even though there is no one-size-fits-all approach to adapt (ODI \& CDKN, 2014).

The magnitude of the drought crisis, and financial and economic limitations raised by the graduation from the LDC category, along with the stock of public debt that rose from 126 to 129.1 percent of GDP in 2018, maintains the country at a high risk of external debt distress - although the current account deficit fell to $4.9 \%$ of GDP in 2018 (WB, 2019). Nonetheless, the grand ambitions in the Government Drought Emergency Plan, were not followed by the design and implementation of innovative financial strategies and mechanisms to support interventions. Without fiscal space to deal with the drought crisis, the country was forced to pledged resources of the order of US\$ 8,225,806 among international partners, as well as ask for other forms of foreign technical assistance. Unfortunately, the proportion of resources devoted to strengthening the institutional capacity of the central and local governments to respond to drought events was marginal, limited to $1,31 \%$ of the total expected budget (US\$ 107,527).

The phases of the Government Drought Emergency Plan (EP), with national coverage, were designed to run for 18 months, began in March 2018. The proposed actions were targeted to mitigate the effects of the drought event in the country, being implemented by the Government of Cabo Verde (GoCV), and supported by FAO, based on three pillars: (i) livestock rescue; (ii) management of water scarcity; and, (iii) creation of jobs for affected families. In its first design, the drought management 
process was purely economic and focused on keeping the levels of agricultural production. In this context, the EP was primarily reactive, adopting a crisis management approach through the provision of existent relief measures, based on limited existing social protection channels. However, with the worsening situation of the drought in the country, it became clear that the ongoing crisis had a direct impact on the increase of households' vulnerability to external shocks (GoCV, 2017b). They were corresponding to cascade effects on different social aspects of the families, women, and children, in particularly vulnerable areas of the country. Therefore, the EP was forced to evolve to a more comprehensive social approach, integrating social vulnerability and long-term resilience building, with support from UN agencies and the international community (GoCV, 2017b). This change in emphasis required a better articulation of local and national governments, while decision-makers needed to be better informed so that they could decide on an improved and more efficient allocation of available resources. Against this background, further planning and risk-informed investments need to be designed not only in prediction/early warning procedures but also in mitigation in agricultural and non-agricultural sectors, which could reduce the future impact of droughts and lessen the need for government interventions (Thurow, 1999; Knutson et al., 2001; Chatzopoulos et al., 2019).

As the drought crisis exposed the nonexistence of formal financial risk management schemes in the country, driving agricultural households to employ detrimental risk mitigation strategies, such as low-risk/low-yield production techniques, selling off productive capital, skipping meals, and withdrawing children from school, retro feeding negative livelihood consequences (GoCV, 2017b). The social dimensions of the crisis, initially ignored, were to be considered in addition to the productive approaches adopted in the EP. It became clear the need to add further actions to the official government response, based on the (i) identification of the socio-economic impacts of the crisis - not only to address the immediate needs of the affected and vulnerable households, but also future needs and demands. Moreover, the national government and stakeholders (ii) found the need to put in place long-term resilience and climate change adaptation programs and policies to mitigate risks and strengthen the country's capability to cope with disaster events and emergencies (GoCV, 2017b). It included the need to build a robust framework to allow future timely, effective, and sustained mechanisms for government planning aligning Disaster Risk Management (DRM) and Climate Change Adaptation (CCA) as part of the National Development Strategy. It is expected to mainstream these themes into the new Strategic Plan for Sustainable Development (2017-2021), and to be aligned with the Sustainable Development Goals (SDGs) (GFDRR, 2017).

In this regard, according to World Bank (2018a), Cabo Verde has recently started designing the legal and institutional framework that set the stage for a comprehensive disaster risk management system. The Government of Cabo Verde is demonstrating its commitment to strengthening the DRM and CCA agenda by adopting a National Disaster Risk Reduction Strategy, in 2017. It seeks to build institutional capacity and to improve coordination among stakeholders to respond in the aftermath of a natural catastrophe, setting up the framework to develop contingency plans, improving the management of fiscal impacts of a disaster, and 
climate-related risks. Besides, it aims to develop channels to drive investment for the safety and resilience of existing public and private infrastructure and redesigning its territorial planning instruments to address the ongoing urbanization and land use challenges. This approach could open doors for future policy reforms aimed at increasing long-term resilience and ability to recover from the adverse impacts of disasters, thereby helping support risk reduction aligned with national development programs and the government's efforts to eliminate extreme poverty and boost climate-resilient pathways in agricultural and non-agricultural sectors.

\section{Lessons learned: the process of building climate change-related risk reduction aimed at achieving climate-resilient pathways}

\subsection{Benefits}

Disaster Risk Reduction and Climate Change Adaptation mainstreaming are continuous processes that many times evolve unsteadily as the awareness of vulnerabilities and risks in society are built, and new uncertainties and opportunities arise. The awareness regarding DRR and CCA and their integration into territorial planning offer the opportunity to push forward the development agenda through policy, legislative, and institutional reforms by allowing the development of a DRM sensitive approach-based that recognizes both local and regional needs and common planning strategies for uncertainty. The embedded an improved institutional articulation that can emerge from the synergy created between design thinking and decision-making processes among involved actors, institutional cooperation, integrated with the establishment of participatory approaches involving the beneficiaries, is central to local administration authorities, the private sector, and civil society organizations achieve climate-resilient pathways.

\subsection{Bottlenecks}

Historic inefficiency of crisis management strategies had led to the development of insufficient risk management approaches, which still must evolve to support the people in vulnerable areas to cope with drought or different disasters before they struck. In this regard, the persistence of actions over time, and the proper allocation of already available resources seems to rise as fundamental issues. Furthermore, foreign dependency appears to be still acting as a shaping factor both in the country and in the Sahel, limiting ambition and the adoption of local solutions and keeping the affected livelihoods more vulnerable to the next disaster event. Policymakers and civil society need to take an honest look at its disaster preparedness and development choices, trying to balance often contested development goals - which in many cases are not adequately integrated into relevant contexts where Human Development is unequal. The recent drought event highlighted the challenge of acquiring bridging DRM and climate finance to support preparedness, as the urgency of the impacts of disasters, especially drought, usually requires visioning, resources, anticipated planning, and adequate management of time. 


\section{Conclusions}

First and foremost, the study paid considerable attention to the emergence of a general corporate social responsibility framework for all emergency operations in the country, according to the nature and urgency of the recent drought event. The Caboverdian Disaster Risk Management and recent development political choices have been consolidating achievements and further strengthening the conditions for risk reduction and climate-resilience building aligned to poverty reduction strategies. Cabo Verde seems to be working to build a comprehensive national framework for risk reduction and sustainable development. However, the dependency of international financial instruments for disaster management and emergency response, limited institutional capacity, and a historical focus on reactively responding to disasters indicate that many of the underlying factors that drive disaster risk in the country are not entirely understood - especially those related to climate change management.

Succeeding, policymakers and civil society have to demonstrate how they value to get policies, strategies, and plans implemented, instead of believing that only pass bold climate and DRM policy is sufficient. Appropriate execution and consistency of actions are vital to building Climate-Resilient Pathways in a more sustainable and fairer world. Secure participative governance mechanisms, complemented by adequate, accessible, and understandable risk information, enabled by modern Legal frameworks re-designed by the systematic integration of assessments into national financial and fiscal planning processes, and funding mechanisms embody the main steps of o broader and ambitious agenda that encourage change, cooperation, and coordination at different levels taking into account local needs and circumstances with viable chance of replicability in similar settings.

The sounder understanding of the social construction of risks because of ill development planning, insufficient human development levels, limited budgetary and fiscal processes are equally necessary to support the integration of both, climate-related risk reduction and adaptation into the government planning processes at various levels.

\section{Acknowledgment}

Special thanks to the Environment, Energy, and Disaster Prevention Unit of the United Nations Office in Cabo Verde. Also, to the Multi-Sectorial Drought Assessment Team from OCHA, under the coordination of the United Nations Office in Cabo Verde. The views in this paper are the views of the author and do not necessarily reflect the views or policies of the United Nations in Cabo Verde, its Board of Directors, or the Governments they represent. The author is very grateful to the anonymous reviewers for their valuable comments and suggestions to improve the manuscript to the present level.

\section{References}

ACP-EU - African, Caribbean and Pacific group of states and Europe Union. Natural Disaster Risk Reduction Program. Cabo Verde: Integrating Disaster Risk and Climate Change Considerations into School Infrastructure Investments. Brussels: ACP; EU; GFDRR; WB, 2019. Available at $<$ https://www.gfdrr.org/en/cabo-verde-integrating-disaster-risk-and-climate-change-considerations-school-infrastructure>. Accessed on: jan. 2020. 
Agnew, C. T.; Chappell, A. Drought in the Sahel. Geo Journal, 48(4), 229-311, 2000. doi: 10.1023/A:1007059403077

Algamal, S. A. An Assessment of Climate-Induced Conflict Risks Over Shared Water Resources in Africa. In: Filho, W. L. (Ed.) The Economy, Social, and Political Elements of Climate Change. Climate Change Management. Berlin: Springer, p. 15-26, 2011. doi: 10.1007/978-3-642-14776$0 \_2$

Bizikova, L.; Burch, S.; Cohen, S.; Robinson, J. Linking sustainable development with climate change adaptation and mitigation. In: O’Brien, K.; Clair, A. St.; Kristoffersen, B. (Eds.). Climate Change, Ethics and Human Security. Cambridge, UK; New York, NY, USA: Cambridge University Press, p. 157-179, 2010.

Caniato, M.; Carliez, D.; Thulstrup, A. Challenges and Opportunities of New Energy Schemes for Food Security in Humanitarian Contexts: A Selective Review. Sustainable Energy Technologies and Assessments, 22, 208-219, 2017. doi: 10.1016/j.seta.2017.02.006

CCAPS - Climate Change and African Political Stability. Water and Security in Niger and the Sahel. Research Brief $N^{o}$ 24. Austin: The University of Texas, 2014.Available at: $<$ https://sites.clas.ufl.edu/africa-sahelresearch/files/researchbrief24-ccaps-web-f.pdf $>$. Accessed on: May 2020.

Chatzopoulos, T.; Domínguez, I. P.; Zampieri, M.; Toreti, A. Climate Extremes, and Agricultural Commodity Markets: A Global Economic Analysis of Regionally Simulated Events. Weather and Climate Extremes, 27, 100193, 2019. doi: 10.1016/j.wace.2019.100193

Couttenier, M.; Soubeyran, R. Drought and Civil War in Sub-Saharan Africa. The Economic Journal, 24, 201-244, 2013. doi: 10.1111/ecoj.12042

CRED - Centre for Research on the Epidemiology of Disasters. 2018 Review of Disaster Events. Brussels: CRED; UCLouvain, 2018. Available at: $<$ https://www.preventionweb.net/files/63266_supplementarydocument2019readyforre.pdf $>$. Accessed on: jan. 2019.

CRED - Centre for Research on the Epidemiology of Disasters; UNISDR - United Nations Office for Disaster Risk Reduction. Economic Losses, Poverty, and Disasters: 1998-2017. Brussels; Geneva: 2018. Available at: $<$ https:// www.unisdr.org/files/61119_credeconomiclosses.pdf $>$. Accessed on: jan. 2019.

CSIRO - The Commonwealth Scientific and Industrial Research Organisation. Climate Change Vulnerability Assessment: Review of Agricultural Productivity. Climate Adaptation Flagship Working Paper no 1. 2008. Available at: $<$ https://publications.csiro.au/rpr/download?pid=procite:9e864d33-5246-43e1-9d7b-e12cd5792e6c\&dsid=DS1>. Accessed on: jan. 2019.

Dabanli, I. Drought Risk Assessment by Using Drought Hazard and Vulnerability Indexes. Natural Hazards and Earth System Sciences, 2018. Available at: https://www. nat-hazards-earth-syst-sci-discuss.net/nhess-2018-129/ nhess-2018-129.pdf

Denton, F.; Wilbanks, T. J. Abeysinghe, A. C.; Burton, I.; Gao, Q.; Lemos, M. C.; Masui, T.; O’Brien, K. L.; Warner, K. Climate-resilient pathways: adaptation, mitigation, and sustainable development. In: Field, C. B.; Barros, V. R.; Dokken, D. J.; Mach, K. J.; Mastrandrea, M. D.; Bilir, T. E.; Chatterjee, M.; Ebi, K. L.; Estrada, Y. O.; Genova, R. C.; Girma, B.; Kissel, E. S.; Levy, A. N.; MacCracken, S.; Mastrandrea, P. R.; White, L. L. (Eds.). Climate Change 2014: Impacts, Adaptation, and Vulnerability. Part A: Global and Sectoral Aspects. The Contribution of Working Group II to the Fifth Assessment Report of the Intergovernmental Panel on Climate Change. Cambridge, UK; New York, NY, USA: Cambridge University Press, p. 1101-1131, 2014.

DW - Deutsche Welle. Cabo Verde Sofre a Pior Seca desde 1977. Praia: DW, 2018.Available at: $<$ https://p.dw.com/p/ 2zR99>. Accessed on: jan. 2020.

EM-DAT - Emergency Events Database. The Emergency Events Database. Brussels: UCLouvain; CRED, 2018. Available at: $<$ https://www.emdat.be/index.php\#letterd $>$. Accessed on: jan. 2019.

EU - European Union. A Coherent EU Strategy for the Sahel. Brussels: European Union, 2012. doi:10.2861/79208

FAO - Food and Agriculture Organization. The Impact of Disasters on Agriculture and Food Security. Rome: FAO, 2015. Available at: $<$ http://www.fao.org/resilience/resources/resources-detail/en/c/346258/>. Accessed on: jan. 2019.

FAO - Food and Agriculture Organization. Press Relea- 
se on the Final Results of the 2017-2018 Agro-pastoral Season and the Food and Nutrition Situation in the Sahel and West Africa. Cadre Harmonisé Analysis June-August 2018. Rome: FAO, 2018. Available at: $<$ http://www.fao. org/emergencies/resources/documents/resources-detail/ en/c/1114249/>. Accessed on: jan. 2019.

FAO - Food and Agriculture Organization; ECA - Economic Commission for Africa. Regional Overview of Food Security and Nutrition. Addressing the threat from climate variability and extremes for food security and nutrition. Rome: FAO Accra, 2018. Available at: $<$ http://www.fao. org/3/CA2710EN/ca2710en.pdf>. Accessed on: feb. 2019

FAO - Food and Agriculture Organization; IFAD - International Fund for Agriculture Development; UNICEF - United Nations Children`s Fund; WFP - World Food Programme; WHO - World Health Organization. The State of Food Security and Nutrition in the World 2017: Building Resilience for Peace and Food Security. Rome: FAO, 2017. Available at: $<$ http://www.fao.org/3/a-I7695e.pdf $>$. Accessed on: jan. 2019.

FAO - Food and Agriculture Organization; IFAD - International Fund for Agriculture Development; UNICEF - United Nations Children`s Fund; WFP - World Food Programme; WHO - World Health Organization. The State of Food Security and Nutrition in the World 2018: Building Climate Resilience for Food Security and Nutrition. Rome: FAO, 2018. Available at: $<$ http://www.fao.org/3/I9553EN/ i9553en.pdf>. Accessed on: jan. 2019.

FES - Friedrich-Ebert-Stiftung. Who Owns the Sahara? Old Conflicts, New Menaces: Mali and the Central Sahara between the Tuareg, Al Qaida, and Organized Crime. Friedrich Ebert Stiftung, Regional Office Abuja. 2011. Available at: $<$ https://library.fes.de/pdf-files/bueros/nigeria/08181. pdf $>$. Accessed on: May 2020.

Fleurbaey, M.; Kartha, S.; Bolwig, S.; Chee, Y. L.; Chen, Y.; Corbera, E.; Lecocq, F.; Lutz, W.; Muylaert, M. S.; Norgaard, R. B.; Okereke, C.; Sagar, A. D. Sustainable Development and Equity. In: Edenhofer, O.; Pichs-Madruga, R.; Sokona, Y.; Farahani, E.; Kadner, S.; Seyboth, K.; Adler, A.; Baum, I.; Brunner, S.; Eickemeier, P.; Kriemann, B.; Savolainen, J.; Schlömer, S.; von Stechow, C.; Zwickel, T.; Minx. J. C. (Eds.). Climate Change 2014: Mitigation of
Climate Change. The Contribution of Working Group III to the Fifth Assessment Report of the Intergovernmental Panel on Climate Change. Cambridge, UK; New York, NY, USA: Cambridge University Press, 2014.

GFDRR - Global Facility for Disaster Risk Reduction. ACP-EU: Natural Disaster Risk Reduction Program. Focus Day on Post Disaster Response and Recovery Frameworks. Brussels: ACP House, 2017. Available at: $<$ https:// www.gfdrr.org/sites/default/files/publication/CABO $\% 20$ VERDE\%20-\%20ACP-EU\%20NDRR\%20Focus\%20 Day\%20presentation\%20-\%209\%20June\%202017.pdf>. Accessed on: feb. 2019.

GoCV - Government of Cabo Verde. National Adaptation Programme of Action on Climate Change (NAPA-Cabo Verde). Praia: National Meteorology and Geophysics Institute; Ministry of Environment and Agriculture, 2007.

GoCV - Government of Cabo Verde. Systematic Inventory Evaluation for Risk Assessment (SIERA). Final Report. Praia: Ministry of Environment, Housing, and Territory, 2013. Available at: $<$ https://www.preventionweb.net/files/ Relatorio\%20SIERA_Cabo\%20Verde.pdf $>$. Accessed on: feb. 2019.

GoCV - Government of Cabo Verde. Resolution No 77/2016 of October 21, 2016. Declaration of Public Calamity on the Island of Santo Antão, due to the Damages Caused by the Rains that Occurred between September 12 and 20, 2016. Praia: Boletim oficial of 10/21/2016.

GoCV - Government of Cabo Verde. Emergency Program for Mitigating Drought and the Bad Agricultural Year of 2017/2018 Campaign (EPM-DA) in Cabo Verde. Praia: Ministry of Agriculture and Environment, 2017a.

GoCV - Government of Cabo Verde. National Disaster Risk Reduction Strategy of Cabo Verde (ENRRD-CV). Praia: UNDP Cabo Verde, 2017b. Available at: $<$ https://www.humanitarianresponse.info/sites/www.humanitarianresponse. info/files/documents/files/enrrd_estrategia_nacional_de_reducao_de_riscos_de_desastres_cabo_verde.pdf $>$. Accessed on: feb. 2019.

GoN - Government of Norway. Strategy for Norway's Efforts in the Sahel Region 2018-2020. Oslo: Ministry of Foreign Affairs, 2018. Available at: $<$ https://www.regjerin- 
gen.no/globalassets/departementene/ud/vedlegg/sikkerhetspolitikk/sahel_strategi_en.pdf $>$. Accessed on: jan. 2019.

GWP CEE - Global Water Partnership Central and Eastern Europe. Drought Risk Management Scheme: a decision support system. Bratislava: Regional Secretariat Slovak Hydrometeorological Institute, 2014. Available at: $<$ https://www.gwp.org/globalassets/global/gwp-cee_images/ idmp-act.5.4-milestone-2.2-updated.pdf $>$. Accessed on: jun. 2019.

Hall, J. W.; Grey, D.; Garrick, D.; Fung, F.; Brown, C.; Dadson, S. G.; Sadoff, C. W. Coping with the Curse of Freshwater Variability: Institutions, Infrastructure, and Information for Adaptation. Science. 346(6.208), 429-430, 2014. doi: 10.1126/Science. 1257890

HDI - Human Development Index. Human Development Reports. Human Development Indices and Indicators: 2018 Statistical Update. United Nations Development Program, 2018. Available at: $<$ http://hdr.undp.org/en/data\#> . Accessed on: jan. 2019.

INFORM - INFORM Index for Risk Management. OCHA. 2019. Available at: $<$ http://www.inform-index.org/>. Accessed on: oct. 2019

IPCC - Intergovernmental Panel on Climate Change. Climate Change 2013: The Physical Science Basis. In: Stocker, T. F.; Qin, D.; Plattner, G. K; Tignor, M.; Allen, S. K.; Boschung, J.; Nauels, A.; Xia, Y.; Bex, V.; Midgley, P. M. (Eds.). The Contribution of Working Group I to the Fifth Assessment Report of the Intergovernmental Panel on Climate Change. Cambridge, UK; New York, NY, USA: Cambridge University Press, 2013. Available at: $<$ https:// www.ipcc.ch/report/ar5/wg1/>. Accessed on: jan. 2019.

IPCC - Intergovernmental Panel on Climate Change. Climate Change 2014: Impacts, Adaptation, and Vulnerability. In: Field, C.B. V.R. Barros, D.J. Dokken, K.J. Mach, M.D. Mastrandrea, T.E. Bilir, M. Chatterjee, K.L. Ebi, Y.O. Estrada, R.C. Genova, B. Girma, E.S. Kissel, A.N. Levy, S. MacCracken, P.R. Mastrandrea, and L.L. White (Eds.). The contribution of Working Group II to the Fifth Assessment Report of the Intergovernmental Panel on Climate Change. Cambridge, UK; New York, NY, USA: Cambridge University Press, 2014a.
IPCC - Intergovernmental Panel on Climate Change. Climate Change 2014: Mitigation of Climate Change. In: Edenhofer, O., R. Pichs-Madruga, Y. Sokona, E. Farahani, S. Kadner, K. Seyboth, A. Adler, I. Baum, S. Brunner, P. Eickemeier, B. Kriemann, J. Savolainen, S. Schlömer, C. von Stechow, T. Zwickel and J.C. Minx (Eds.). The Contribution of Working Group III to the Fifth Assessment Report of the Intergovernmental Panel on Climate Change. Cambridge, UK; New York, NY, USA: Cambridge University Press, 2014b.

IPCC - Intergovernmental Panel on Climate Change. Summary for Policymakers. In: Global warming of $1.5^{\circ} \mathrm{C}$. In: Masson-Delmotte, V. P.; Zhai, H.O.; Pörtner, D.; Roberts, J.; Skea, P.R.; Shukla, A.; Pirani, W.; Moufouma-Okia, C.; Péan, R.; Pidcock, S.; Connors, J.B.R.; Matthews, Y.; Chen, X.; Zhou, M.I.; Gomis, E.; Lonnoy, T.; Maycock, M.; Tignor, T.; Waterfield (Eds.). An IPCC Special Report on the impacts of global warming of $1.5^{\circ} \mathrm{C}$ above pre-industrial levels and related global greenhouse gas emission pathways in the context of strengthening the global response to the threat of climate change, sustainable development, and efforts to eradicate poverty. Geneva: World Meteorological Organization, 2018. Available at: $<$ https://www.ipcc.ch/ sr15/chapter/spm/>. Accessed on: jan. 2019.

Jia, H.; Wang, D. P. J. Risk Mapping of Integrated Natural Disasters in China. Natural Hazards, 80(3), 2023- 2035, 2016. doi: 10.1007/s11069-015-2057-3

Karami, E. Drought Management and the Role of Knowledge and Information. In: Proceedings of the National Conference on Challenges and Strategies of Drought. Shiraz, Iran, 23-24 May 2009.

Kath, J.; Mushtaq, S.; Henry, R.; Adeyinka, A.; Stone, R. Index Insurance Benefits Agricultural Producers Exposed to Excessive Rainfall Risk. Weather and Climate Extremes, 22, 1-9, 2018. Available at: https://www.sciencedirect. com/science/article/pii/S2212094718300513?dgcid=raven_sd_aip_email

Knutson, G. L.; Blomstedt, M. L.; Slaughter, K. Results of a Rapid Appraisal Study: Agricultural Producers' Perceptions of Drought Vulnerability and Mitigation-Howard County, Nebraska. Drought Network News (1994-2001), 13(1), 2001. Available at: http://digitalcommons.unl.edu/ 
droughtnetnews/20

Lacoste, Y. Sahara, Perspectives et Illusions Géopolitiques. Hérodote, 142(3), 12-41, 2011.

Lin, M. L.; Chu, C. M.; Tsai, B. W. Drought risk assessment in western Inner-Mongolia. International Journal of Environmental Research, 5(1), 139e148, 2011.

Manyena, S. B. The Concept of Resilience Revisited. Disasters, 30(4), 433-450, 2006.

Marvel, K.; Cook, B. I.; Bonfils, C. J. W.; Durack, P. J.; Smerdon, J. E.; Williams, A. P. Twentieth-Century Hydroclimate Changes Consistent with Human Influence. Nature, 569(7754), 59-65, 2019. doi:10.1038/s41586-019-1149-8

Masih, I.; Maskey, S.; Mussá, F. E. F.; Trambauer, P. A Review of Droughts on the African Continente: A Geopastial and Long-Term Perspective. Hydrology, and Earth Systems. Science, 18, 3635-3649, 2014. doi:10.5194/hess18-3635-2014

McSweeney, C. N. The UNDP Climate Change Country Profiles: Improving the Accessibility of Observed and Projected Climate Information for Studies of Climate Change in Developing Countries. Bulletin of the American Meteorological Society, 91, 157-166, 2010.

Miyan, M. A. Droughts in Asian Least Developed Countries: Vulnerability and Sustainability. Weather and Climate Extremes, 7, 8-23, 2015. doi: 10.1016/j.wace.2014.06.003

OCHA - UN Office for the Coordination of Humanitarian Affairs. Sahel Regional Strategy. 2013. Available at: $<$ https:// reliefweb.int/sites/reliefweb.int/files/resources/SahelStrategy2013_Dec2012.pdf>. Accessed on: jan. 2019.

OCHA - UN Office for the Coordination of Humanitarian Affairs. Sahel 2014-2016 Regional Humanitarian Response Strategy Reviewed. 2017. Available at: $<$ https://reliefweb. int/sites/reliefweb.int/files/resources/Sahel-EYReport-2016-LowRes.pdf $>$. Accessed on: jan. 2019.

OCHA - UN Office for the Coordination of Humanitarian Affairs. World Humanitarian Data and Trends 2018. 2018. Available at: $<$ https://reliefweb.int/sites/reliefweb.int/files/ resources/WHDT2018_web_final_spread.pdf $>$. Accessed on: jan. 2019.
ODI - Overseas Development Institute; CDKN - Climate Development Knowledge Network. The IPCC's Fifth Assessment Report: What is in It for Africa? Overseas Development Institute and Climate and Development Knowledge Network, 2014. Available at: $<$ https://cdkn.org/wp-content/ uploads/2014/04/AR5_IPCC_Whats_in_it_for_Africa. pdf>. Accessed on: jan. 2019.

OECD - Organization for Economic Co-operation and Development. Transition Finance in the least Developed Countries and Small Island Developing States: Cabo Verde Country Pilot. Paris: Development Assistance Committee. (DCD/DAC (2019), 2019. Available at: $<$ http://www.oecd. org/officialdocuments/publicdisplaydocumentpdf/?cote=$\mathrm{DCD} / \mathrm{DAC}(2019) 4 \&$ docLanguage $=\mathrm{En}>$. Accessed on: jan. 2019.

Pei, W.; Fu, Q.; Li, D. L. T. Assessing Agricultural Drought Vulnerability in the Sanjiang Plain Based on a 15 Improved Projection Pursuit Model. Natural Hazards, 82(1), 683-701, 2016. doi: 10.1007/s11069-016-2213-4

Porkka, M.; Gerten, D.; Schaphoff, S.; Siebert, S.; Kummu, M. Causes, and Trends of Water Scarcity in Food Production. Environmental Research Letters, 11, 015001, 2016. doi: 10.1088/1748-9326/11/1/015001

Rajsekhar, D.; Singh, V. P.; Mishra. A. K. Integrated Drought Causality, Hazard, and Vulnerability Assessment 20 for Future Socioeconomic Scenarios: An Information Theory Perspective. Journal of Geophysics Research Atmosphere, 120, 6346-6378, 2015. doi: 10.1002/2014JD022670

Rojas, O. Agricultural Extreme Drought Assessment at Global Level Using the FAO-Agricultural Stress Index System (ASIS). Weather and Climate Extremes, 27, 100184, 2018. doi: 10.1016/j.wace.2018.09.001

Shahid, S.; Behrawan, H. Drought risk assessment in the western part of Bangladesh. Natural Hazards, 46, 391-413, 2008. doi: 10.1007/s11069-007-9191-5

STRATFOR. Africa's Tuareg Dilemma. Worldview. 2012. Available at: $<$ https://worldview.stratfor.com/article/africas-tuareg-dilemma $>$. Accessed on: May 2020.

Thulstrup, A. W.; Habimana, D.; Joshi, I.; Oduri, S. M. Uncovering the Challenges of Domestic Energy Access in the Context of Weather and Climate Extremes in Somalia. 
Weather and Climate Extremes, 27, 100185, 2018.

Thurow, T. L.; Taylor, C. A., Jr. Viewpoint: The Role of Drought in Range Management. Journal of Range Management, 52, 413-419, 1999.

UNDESA - United Nations Department of Economic and Social Affairs. Handbook on the Least Developed Country Category: Inclusion, Graduation, and Special Support Measures. 2015. Available at: $<$ http://www.un.org/en/development/desa/policy/cdp/cdp_publications/2015cdphandbook. pdf>. Accessed on: jan. 2019.

UNDESA - United Nations Department of Economic and Social Affairs. Country profile: Cabo Verde. 2018a. Available at: $<$ https://www.un.org/development/desa/dpad/ wp-content/uploads/sites/45/LDC_Profile_CaboVerde. pdf $>$. Accessed on: jan. 2019.

UNDESA - United Nations Department of Economic and Social Affairs. The Least Developed Country Category: 2018 Country Snapshots. 2018b. Available at: $<$ https:// www.un.org/development/desa/dpad/wp-content/uploads/ sites/45/Snapshots2018.pdf>. Accessed on: jan. 2019.

UNDP - United Nations Development Program. Screening Tools, and Guidelines to Support the Mainstreaming of Climate Change Adaptation into Development Assistance. A Stocktaking Report. New York: UNDP, 2010. Available at: $<$ http://content-ext.undp.org/aplaws_publications/2386693/UNDP\%20Stocktaking\%20Report $\% 20$ CC\%20mainstreaming\%20tools.pdf $>$. Accessed on: jan. 2019.

UNDRR - United Nations Office for Disaster Risk Reduction. Global Assessment Report on Disaster Risk Reduction. Geneva: UNDRR, 2019. Available at: $<$ https://www.unisdr. org/we/inform/gar>. Accessed on: jan. 2020.

UNISDR - United Nations Office for Disaster Risk Reduction. 2018: Extreme Weather Events Affected 60m People. Geneva: UNISDR, 2019. Available at: $<$ https://reliefweb.int/ report/world/2018 extreme-weather-events-affected-60m-people>. Accessed on: jan. 2019.

Verdon-Kidd, D.C.; Kiem, A.S. Quantifying Drought Risk in a Nonstationary Climate. Journal of Hydrometeorology. 11(5), 1019-1031. 2010. doi: 10.1175/2010JHM1215.1
WB -World Bank. Food Security, and Conflict: Agriculture and Rural Development. Washington, DC: WB, 2011. Available at: $<$ http://documents.worldbank.org/curated/ en/622491468331234468/Food-security-and-conflict>. Accessed on: jan. 2019.

WB - World Bank. Competitiveness for Tourism Development. Washington D.C., USA: World Bank, 2016. Available at: $<$ http://projects.worldbank.org/P146666?lang=en $>$. Accessed on: jun. 2019.

WB - World Bank. Cabo Verde Disaster Risk Management Development Policy Financing with Cat DDO. Projects and Operations. Washington D.C., USA: World Bank, 2018a. Available at: $<$ http://projects.worldbank.org/ P160628?lang=pt $>$. Accessed on: jun. 2019.

WB -World Bank. Concept Program Information Document (PID) - Cabo Verde Disaster Risk Management Development Policy Credit and Loan with Cat DDO - P160628 (English). Washington, D.C.: World Bank Group, 2018b. Available at: $<$ http://documents.worldbank.org/curated/ en/125621531480106694/pdf/Concept-Program-Information-Document-PID-Cabo-Verde-Disaster-Risk-Management-Development-Policy-Credit-and-Loan-with-Cat-DDO-P160628.pdf>. Accessed on: jan. 2019.

WB - World Bank. Republic of Cabo Verde: Adjusting the Development Model to Revive Growth and Strengthen Social Inclusion. Systematic Country Diagnostic (SCD). Washington D.C., USA: World Bank, 2018c. Available at: $<$ http://documents.worldbank.org/curated/ en/875821538129394201/pdf/130289-REVISED-SCD-P159323-PUBLIC.pdf $>$. Accessed on: jun. 2019.

WB - World Bank. The World Bank in Cabo Verde. Praia: World Bank, 2019. Available at: $<$ http://www.worldbank. org/en/country/caboverde $>$. Accessed on: jun. 2019.

WC - Wikimedia Commons. Sahel Map - Africal. 2018. Available at: $<$ https://commons.wikimedia.org/wiki/File:Sahel_Map-Africa_rough.svg >. Accessed on: jan. 2019.

WDCC - Western Drought Coordination Center. How to Reduce Drought Risk. 1998. Available at: $<$ https://drought. unl.edu/archive/Documents/NDMC/Planning/risk.pdf > . Accessed on: jan. 2019 
Wilbanks, T. J., Sathaye, J. Integrating Mitigation, and Adaptation as Responses to Climate Change: A Synthesis. Mitigation and Adaptation Strategies for Global Change, 12, 957-962, 2007.

Wilhite, D. A. Moving Toward Drought Risk Management: The need for global strategy. 2003.
WWAP - United Nations World Water Assessment Programme; UN-WATER. The United Nations World Water Development Report: Nature-Based Solutions for Water. Paris: UNESCO, 2018. Available at: $<$ https://unesdoc.unesco.org/ark:/48223/pf0000261424>. Accessed on: jan. 2019.

Zarafshani, K.; Sharafi, L.; Azadi, H.; Van Passel, S., Vulnerability Assessment Models to Drought: Toward a Conceptual Framework. Sustainability, 8(6), 588, 2016. doi: $10.3390 /$ su 8060588 